\title{
Coastal habitat engineers and the biodiversity in marine sediments
}

\author{
Karsten Reise · Tjeerd J. Bouma • \\ Sergej Olenin · Tom Ysebaert
}

Published online: 12 February 2009

(C) Springer-Verlag and AWI 2009

Over a long time in the history of earth in Precambrian oceans, otherwise loose sediments were generally sealed by tiered microbial mats (Meysman et al. 2006). These stabilizers of sedimentary habitats were probably first undermined and then overturned by burrowing worms evolved at the shore, trying to keep away from the vagaries of the tidal sediment surface but still feeding on the microbial biomass above. Their synergistic bioturbation created a new habitat in an extended sediment layer, gardened by digging, irrigating and letting overlying water to flush in and out. This habitat amelioration allowed for a diversified and productive benthic food web. Sluggish epibenthic creatures might have been relegated to marginal zones together with tight mats of microbial stabilizers.

K. Reise $(\bowtie)$

Alfred Wegener Institute for Polar and Marine Research,

Wadden Sea Station Sylt, Hafenstrasse 43,

25992 List/Sylt, Germany

e-mail: karsten.reise@awi.de

T. J. Bouma - T. Ysebaert

Centre for Estuarine and Marine Ecology,

Netherlands Institute of Ecology (NIOO-KNAW),

Yerseke, The Netherlands

T. Ysebaert

Wageningen IMARES,

Institute for Marine Resources and Ecosystem Studies,

Yerseke, The Netherlands

S. Olenin

Unifob Environmental Research, Bergen, Norway

S. Olenin

Coastal Research and Planning Institute,

Klaipeda University, Klaipeda, Lithuania
When the earth warmed up and sea level increased, the innovative Cambrian revolution swamped the bottom of the sea with animals supported by skeletons which now bioturbated the sediments from above and below, while sponges and others began to create reefs of epibenthic suspension feeders. Complex biogenic benthic habitats arose, vanished and then were re-invented over and over again in the course of evolution until today. Erwin (2008) suggests an overall increase in ecosystem engineering in the course of time. In this special issue of Helgoland Marine Research we focus on macrobenthic engineers which either bioturbate or stabilize the sediments by their activity (allogenic) or their bodily structures (autogenic ecosystem engineers sensu Jones et al. 1994), respectively. What are their effects on species and functional diversity in modern coastal sediments?

Fisheries with their bottom gear have harassed and with bottom cultures of mussels and oysters have proliferated epibenthic structures. Human coastal engineering often enhanced physical sediment mobilitity to the detriment of autogenic engineers. In addition to the direct effects on biodiversity, many are mediated by species with strong effects on the sedimentary environment. The contributions in this issue attempt to reveal the interplay between inhibiting and facilitating effects on organisms smaller than the engineers which are physically dominating the benthic habitat. As a characteristic of sheltered sediment shores, vascular plants grow in swards or meadows. These tend to facilitate epibenthic fauna, hydrobiid snails in particular, and have mixed and species-specific effects on infauna (Bouma et al. 2009b). This is mainly caused by the physical structures above and below the ground, and by calming down the hydrodynamics. In the extreme this may enhance anoxia in the sediment but at more exposed areas the sheltering and stabilizing effect of the canopy will dominate. Brun et al. 
(2009) show a facilitative effect on the filter-feeding rate of cockles. Apparently, the drop in flow velocity did not lead to food depletion in the suspension feeders.

Bioturbating lugworms enhance sediment mobility at the surface. The exclusion of these allogenic sediment engineers had negative effects on other burrowing worms, while tube-building worms took advantage (Volkenborn et al. 2009). Their protruding tube caps provided attachment for algal tufts and filiform thalli. These in turn seem to facilitate the settlement of young clams. One of the tube worms was the sandmason Lanice conchilega which at high densities can also exclude lugworms. Overall, patchiness of worms destabilizing and stabilizing sediments contributes to the biodiversity of a shore. On low intertidal and subtidal sandy bottoms with strong currents, L. conchilega may achieve very high densities and then generates persistent, elevated sediment reefs with a high diversity of associated organisms (Rabaut et al. 2009). This is an ideal model organism for studying the sediment-animal-interactions contributing to the strength of a benthic engineer in modifying its habitat and thereby affecting other species.

The most conspicuous habitat transformations on sediment shores are achieved by epibenthic suspension feeders, forming bioherms, variably termed clusters, beds or reefs. Most common are mussels and oysters. Buschbaum et al. (2009) compared the effects on benthic biodiversity by different mytilid mussels at four sediment coasts located in distant parts of the world. Although these generally increased biodiversity at the scale of an entire shore, mussel beds not always supported a higher species diversity compared to ambient sediments. This is because mussels behave differently, varying between endobenthic, semi- and epibenthic mode of life, and because responses of the local species pool differed between the regions. These comparisons seem to be a fruitful approach to continue. Also culture plots of the mussel fishery exert changes in benthic biodiversity (Ysebaert et al. 2009). Enrichment with biodeposits shifts the species spectra from that of sandy to more muddy bottoms with more opportunistic species.

Among beds of epibenthic suspension feeders, universal invaders transferred by ship and aquaculture all over the world are an increasing phenomenon, most notably exemplified by the zebra mussel Dreissena polymorpha and the Pacific oyster Crassostrea gigas. Zebra mussels invaded lakes, rivers and coastal lagoons. Zaiko et al. (2009) have shown that not only beds of live mussels raise biodiversity relative to ambient bare sediment but accumulations of zebra mussel shells exhibit a similar effect. At the coasts of the North Sea, Pacific oysters are invading coastal defence structures and sediments slightly above and below low tide level, often occupying sites where mussel beds had been before (Smaal et al. 2009). It has been shown by means of a field experiment that mussels and oysters function differently as habitat engineers and entail different abundances in the associated fauna (Kochmann et al. 2008).

Within the framework of the European Network of Excellence on Marine Biodiversity and Ecosystem Functioning (MarBEF), an initiative on The role of native and/or invasive ecosystem engineers in explaining biodiversity cooperated to develop working hypotheses on this subject. These were advanced at workshops in January 2006 at NIOO-CEME in Yerseke, The Netherlands and in April 2007 at Klaipeda University, Lithuania, and are presented by Bouma et al. (2009a). We thank all workshop participants, the organizers and the many referees who improved the contributions to this special issue on coastal habitat engineers and the biodiversity in marine sediments.

\section{References}

Bouma TJ, Olenin S, Reise K, Ysebaert T (2009a) Native and alien ecosystem engineers and the biodiversity in coastal sediments. Helgol Mar Res 63. doi: 10.1007/s10152-009-0146-y

Bouma TJ, Ortells V, Ysebaert T (2009b) Comparing biodiversity effects among ecosystem engineers of contrasting strength: macrofauna diversity in Zostera noltii and Spartina anglica vegetations. Helgol Mar Res 63. doi: 10.1007/s10152-008-0133-8

Brun FG, Zetten E van, Cacabelos E, Bouma TJ (2009) Role of two contrasting ecosystem engineers (Zostera noltii and Cymodocea nodosa) on the food intake rate of Cerastoderma edule. Helgol Mar Res 63. doi: 10.1007/s10152-008-0134-7

Buschbaum C, Dittmann S, Hong JS, Hwang IS, Strasser M, Thiel M, Vadivia N, Yoon SP, Reise K (2009) Mytilid mussels: global habitat engineers in coastal sediments. Helgol Mar Res 63. doi: 10.1007/s10152-008-0139-2

Erwin DH (2008) Macroevolution and ecosystem engineering, niche construction and diversity. Trends Ecol Evol 23:304-310

Jones CG, Lawron JH, Shachak M (1994) Organisms as ecosystem engineers. OIKOS 69:373-386

Kochmann J, Buschbaum C, Volkenborn N, Reise K (2008) Shift from native mussels to alien oysters: differential effects of ecosystem engineers. J Exp Mar Biol Ecol 364:1-10

Meysman FJR, Middelburg JJ, Heip CHR (2006) Bioturbation: a fresh look at Darwin's last idea. Trends Ecol Evol 21:688-695

Rabaut M, Vincx M, Degraer S (2009) Do Lanice conchilega (sandmason) aggregations classify as reefs? Helgol Mar Res 63. doi: 10.1007/s10152-008-0137-4

Smaal AC, Kater BJ, Bol J, Wijsman J (2009) Introduction and proliferation of the Pacific oyster Crassostrea gigas in Dutch waters. Helgol Mar Res 63. doi: 10.1007/s10152-008-0138-3

Volkenborn N, Robertson D, Reise K (2009) Sediment destabilizing and stabilizing bio-engineers on tidal flats: cascading effects of experimental exclusion. Helgol Mar Res 63. doi: 10.1007/ s10152-008-0140-9

Ysebaert T, Hart M, Herman PMJ (2009) Impacts of bottom and suspended cultures of mussels Mytilus spp. on the surrounding sedimentary environment and macrobenthic biodiversity. Helgol Mar Res 63. doi: 10.1007/s10152-008-0136-5

Zaiko A, Olenin S, Daunys D (2009) Habitat engineering by the invasive zebra mussel Dreissena polymorpha (Pallas) in a boreal coastal lagoon: impact on biodiversity. Helgol Mar Res 63. doi: 10.1007/s10152-008-0135-6 